\title{
Sympatric Bat Species Prey Opportunistically on a Major Moth Pest of Pecans
}

\author{
Elizabeth C. Braun de Torrez ${ }^{1, *}$ (D), Veronica A. Brown ${ }^{2}$, Gary F. McCracken ${ }^{2}$ and \\ Thomas H. Kunz ${ }^{1}$ \\ 1 Department of Biology, Boston University, Boston, MA 02215, USA; kunz@bu.edu \\ 2 Department of Ecology and Evolutionary Biology, The University of Tennessee, Knoxville, TN 37996, USA; \\ vabrown@utk.edu (V.A.B.); gmccrack@utk.edu (G.F.M.) \\ * Correspondence: ecbraun@bu.edu; Tel.: +01-617-895-7937
}

Received: 13 October 2019; Accepted: 7 November 2019; Published: 13 November 2019

check for updates

\begin{abstract}
Native predators provide undervalued pest suppression services to agriculture. Studies of pest consumption by insectivorous bats tend to focus upon single species in large, centralized colonies, while bats dispersed in small groups within the agricultural matrix often go unnoticed. Pecan trees, Carya illinoinensis, and the destructive pecan nut casebearer (PNC) moth, Acrobasis nuxvorella, comprise a tightly linked host-parasite system in a widespread agroecosystem native to North America. Here we use a quantitative polymerase chain reaction (qPCR) assay of fecal DNA to document predation on PNC moths by an assemblage of sympatric bat species across episodic peaks in PNC abundance. Although five species of bats consume PNC moths, greater predation by a solitary tree-roosting bat (eastern red bat, Lasiurus borealis) than other species is suggested by a higher frequency of PNC occurrence and quantity of PNC gene copies in fecal samples. Consumption of PNC by bats during all documented peaks in moth activity suggests that predation pressure occurs throughout the PNC season. Our results highlight the need to consider multi-species assemblages and different foraging strategies when assessing pest suppression services, particularly in agroforestry or tree crops. Assessing the diet of only common or easily captured species limits our ability to accurately document pest consumption by bats.
\end{abstract}

Keywords: agriculture; diet; eastern red bat; ecosystem services; fecal analysis; pest suppression; quantitative PCR; pecan agroecosystem

\section{Introduction}

Native predator assemblages provide critical but undervalued pest suppression services across agricultural landscapes worldwide [1,2]. The presence of these predators can help maintain insect populations at sustainable levels and dampen episodic outbreaks of destructive pests [3]. Because they do not depend upon a single species, assemblages of generalist predators are important pest regulators and suppressors in systems with complex food webs and diverse pest species [4]. In contrast to specialist predators, generalists remain abundant in areas between pest outbreaks, and may recruit rapidly when pest numbers surge, which enables generalists to: Prevent or delay an outbreak $[5,6]$, impede the range expansion of invasive pests $[7,8]$ and delay the evolution of resistance to pesticides [3,9]. Generalists may also complement specialists by maintaining pests at low abundances once specialists reduce the pest numbers [3]. Similarly, complementarity among multiple predators with different foraging strategies can enhance the efficacy of biological control in agricultural systems [10].

Most insectivorous bats are considered to be generalist predators, and are increasingly recognized for the services they provide to agriculture through their consumption, regulation and suppression of insect pests [11-14]. With the advent of molecular analyses of fecal DNA, our ability to characterize 
bat diets and identify predation on agricultural pests has improved dramatically [15-18]. However, we are only beginning to understand pest consumption by a handful of species in this hyper-diverse order. Different foraging strategies and morphologies among bat species and spatio-temporal changes in prey communities may lead to variation in predation success and pest consumption by bats. For example, species adapted for foraging in open areas may have large impacts upon pests that occur in row crop agriculture [13], while species adapted for foraging in dense vegetation may be key predators of pests in more structurally complex agroforestry systems [19]. Further, studies of agricultural pest consumption by bats have primarily focused on single bat species located in large, centralized colonies, such as caves or bat houses, that enable the convenient capture and sampling of guano (e.g., $[15,16,20,21])$. Bats that roost solitarily or in small groups in trees dispersed within the agricultural matrix often go unnoticed for their role in pest consumption, but these may complement—or even rival—species that occur in higher densities by preying on pests in these more cluttered environments. Tracking predation on specific pest items over time by multiple species within predator assemblages is a critical first step for understanding variation in, and ultimately managing for, the ecosystem services of mobile organisms such as bats $[22,23]$.

Bats may provide an important but under-explored pest suppression service in pecan agroecosystems [21], a widespread and economically valuable agroforestry system native to the southern United States (U.S.) and Mexico [24,25]. The pecan nut casebearer (PNC) moth, Acrobasis nuxvorella (Neunzig; Lepidoptera: Pyralidae) is a destructive pest that feeds exclusively on pecan nuts, and has closely evolved with pecan trees (Carya illinoinensis; Fagales: Juglandaceae) [24,25]. Pecan trees grow naturally in alluvial floodplain forests along the Mississippi River Valley, and are cultivated in 15 states across the southern U.S. (Figure 1). As cultivation of pecan trees has expanded beyond their historic range, PNC distribution has similarly expanded [26]. PNC moths are small (8-10mm; Figure 2a), exclusively nocturnal, and exhibit a short, darting flight within the pecan canopy [27], with minimal dispersal outside of the orchards [28]. They are most active around pecan nuts, and are present in orchards for only 2-3 weeks during each generation [25]. Two to four generations of PNC larvae feed on pecan nuts during each growing season, and the pest overwinters as immature larvae in pecan shoots [27]. Female moths lay 150-200 eggs in their lifetime [29], allocating one egg per nut cluster [30]. Each first instar larva bores into up to five nuts, with second and third instar larvae damaging one or two additional nuts [31] (Figure 2b). PNC is the primary pest of pecans, causing near complete crop loss if left uncontrolled $[27,32,33]$.

Recent evidence documents that bats consume PNC moths [21], but we know nothing about consumption among different bat species, across time, or impacts on pecan harvest. We previously documented relatively low consumption of PNC (in 1.4\% of fecal samples tested) by Brazilian free-tailed bats, Tadarida brasiliensis, occupying bat houses in pecan orchards in Texas and Georgia [21]. Brazilian free-tailed bats are known to forage in open, uncluttered airspace [34], and these bats typically fly away from orchards upon emergence, rather than foraging within the orchards. Due to their small size and flight behavior within the foliage of the pecan canopy, PNC moths may have little exposure to these open-air predators. Further reducing their risk of predation by bats, PNC moths have ultrasound-sensitive (tympanate) ears capable of detecting bats and are suspected to concentrate their activity during times (00:00-04:00) when some bats tend to have reduced activity [25,35]. Several other bat species that are documented to roost or forage in pecan orchards [36], including eastern red bats (Lasiurus borealis; Figure 2c,d), cave myotis (Myotis velifer), evening bats (Nycticeius humeralis) and tri-colored bats (Perimyotis subflavus), have wing morphologies adapted to flight in cluttered habitats, are known to forage below and within forest canopies, and have smaller foraging ranges than Brazilian free-tailed bats [37]. In other parts of their range, these species all consume moths to varying degrees [38-40], particularly eastern red bats that prey heavily on moths, including many species with tympanate ears $[39,41]$. We hypothesize that this local bat assemblage may have higher rates of PNC predation in pecan agroecosystems than that indicated by high-flying Brazilian free-tailed bats alone. 


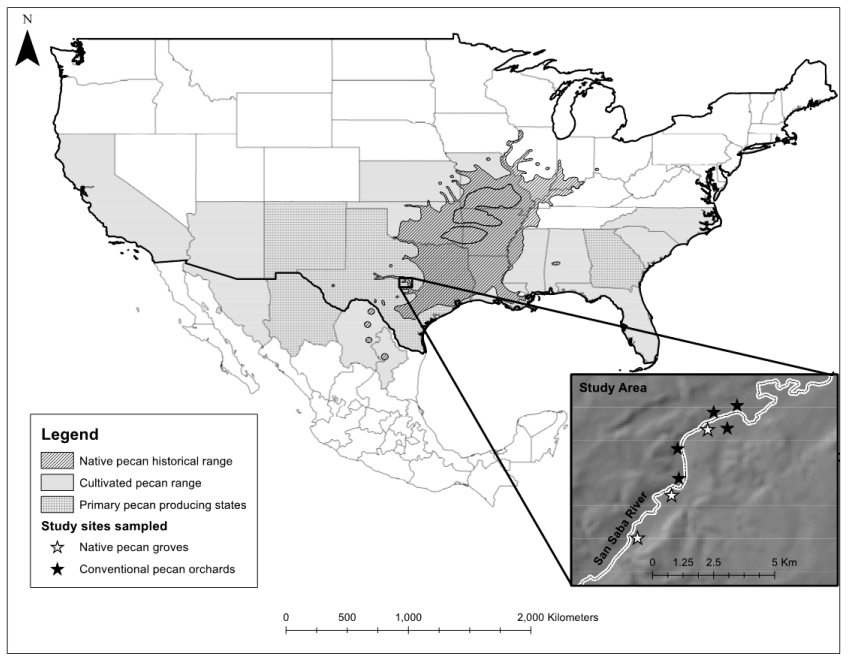

Figure 1. Map of our study area in San Saba county, Texas, U.S.A. (inset box), where we documented consumption of the pecan nut casebearer (PNC) moth (Acrobasis nuxvorella) by an assemblage of insectivorous bats. Hashed lines depict the historical range of native pecan trees, and gray shading represents the current extent of cultivated pecan trees across the U.S.A. and Mexico. Primary pecan producing states (stippled and shaded) include: Georgia, Texas and New Mexico, U.S.A. and Chihuahua, Mexico.

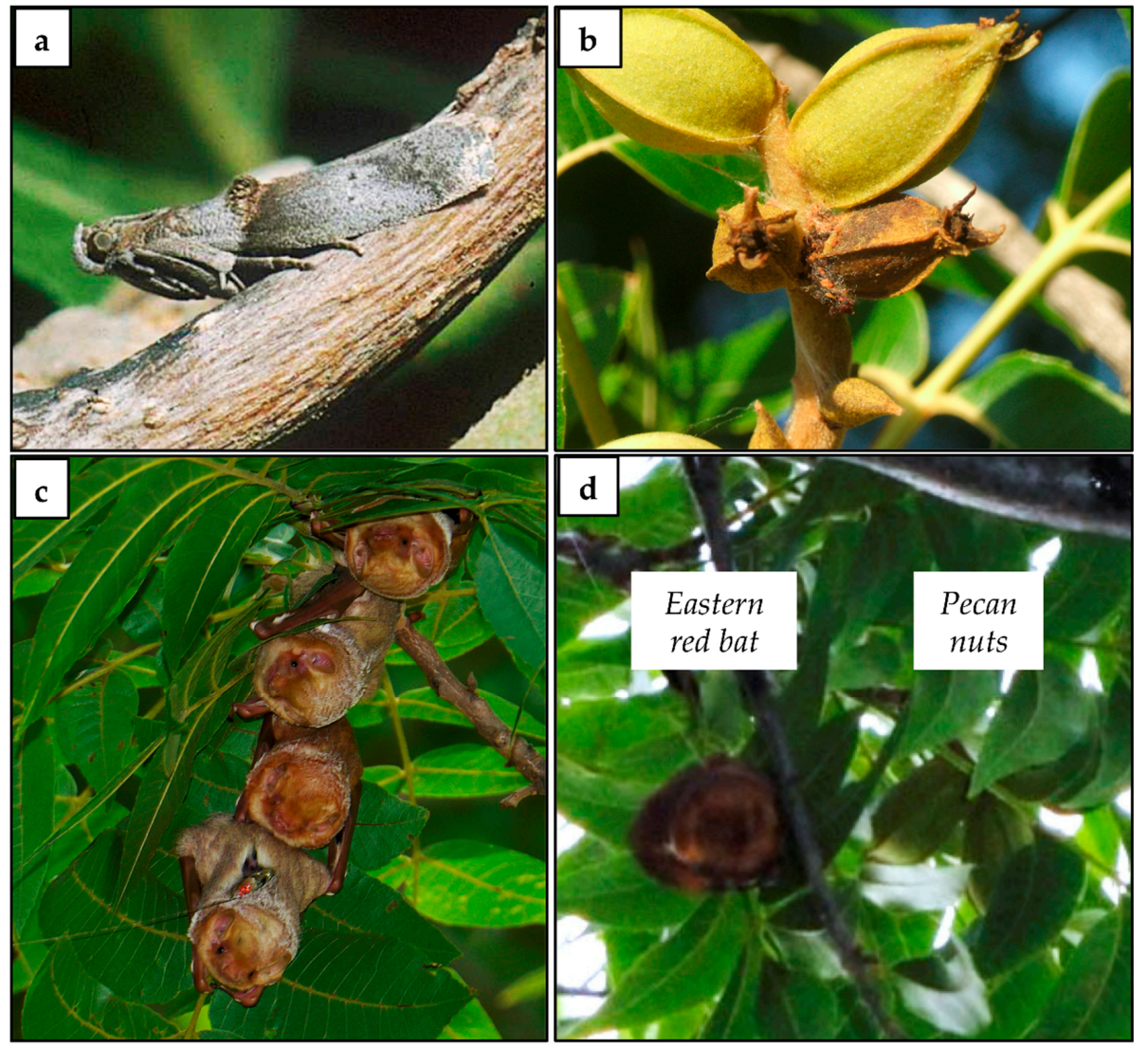

Figure 2. Photographs taken in pecan trees, Carya illinoinensis, of: a) Adult pecan nut casebearer moth (PNC), Acrobasis nuxvorella, resting on a pecan branch (photo credit: Bill Ree, Texas A\&M Agrilife Extension); b) pecan nut cluster damaged by PNC larvae and showing characteristic PNC frass and webbing; c) eastern red bats, Lasiurus borealis, roosting within the foliage of pecan trees, and d) eastern red bat roosting next to immature pecan nuts. (Photo credits (B-D): Elizabeth Braun de Torrez, Boston University; Location: Native pecan groves, San Saba County, Texas, U.S.A.). 
Here we used PNC-specific primers and quantitative polymerase chain reaction (qPCR) analysis of fecal DNA to track species-specific and temporal patterns in the consumption of PNC by an assemblage of generalist bat predators. We investigated variation in PNC consumption among bat species, across seasonal episodic peaks in PNC moth activity, and relative to the estimated PNC availability in pecan agroecosystems. We expected to find differences in consumption based on differing foraging strategies among bat species, and opportunistic predation on PNC in response to changes in relative prey availability. Because these moths are small, episodic and likely evolved to avoid bat predation, we predicted to find: 1) Greater consumption by clutter-adapted forest bats that may be able to exploit PNC more readily than that of open-space aerial insectivores, and 2) greater consumption of PNC on nights of peak moth activity and early in the morning when moths have been found to be most active.

\section{Materials and Methods}

All research methods were conducted in accordance with the Boston University Institutional Animal Care and Use Committee under IACUC protocol \#08-016 and Texas Parks and Wildlife, Scientific Permit Number SPR-0305-058.

\subsection{Study Area}

We conducted this study in San Saba County, Texas, within the Edward's Plateau Ecoregion [42] during two field seasons (year one: April-June 2008; year two: April-August 2009). San Saba County is the site of the first grafted pecans, ranks $2^{\text {nd }}$ in the acreage of pecan orchards in Texas, and $6^{\text {th }}$ in pecan acreage in the U.S.A. [43,44]. We sampled bats in eight sites across two types of pecan agroecosystem: Native pecan groves $(n=3)$-thinned of competing tree species and organically managed, and conventional pecan orchards $(n=5)$-cultivated pecan trees with frequent use of pesticides, fertilization, soil tillage, branch cropping and flood irrigation (Figure 1).

\subsection{Sample Collection}

\subsubsection{Collection of Feces}

We captured bats with mist nets (38 mm mesh, $9 \mathrm{~m}$ and $12 \mathrm{~m}$ nets; Avinet, Inc., Dryden, NY, U.S.A.) on 53 nights coinciding with periods of expected pecan nut casebearer (PNC) moth generations, using two triple-high mist net systems (Bat Conservation and Management, Inc., Carlisle, PA, U.S.A.) and two ground level net systems. Net locations were selected to conceal nets from bats in flight, and new locations within a site were selected each sampling night. Nets were open from dusk (20:30-21:00) until dawn (06:00-06:30) and monitored every 15 minutes. Species, sex, age and reproductive status, as well as body mass and forearm length, were recorded for all captured bats. Bats were held in clean, cloth bags for up to three hours. Feces were collected using ethanol flame-sterilized forceps, and placed into $2 \mathrm{ml}$ screw-cap microtubes (Sarstedt) with silica gel desiccant (4-10 mesh, Thermo Fisher Scientific, Waltham MA, U.S.A. ) and stored at $-20^{\circ} \mathrm{C}$.

\subsubsection{PNC Availability - Pheromone Traps}

We monitored PNC moth activity in each mist net site nightly over the study period using Intercept-A pheromone traps with sticky liners and rubber septa lures $(100 \mu \mathrm{g}$ 9E, 11Z-hexadecadienal and $10 \mu \mathrm{g}$ of butylated hydroxyl toluene) hung from tree branches $\sim 2 \mathrm{~m}$ above the ground [28]. Pheromone traps attract only reproductively-active male moths, providing an index of the relative abundance of the target moth species. Because these traps have an estimated effective catch area of one tree [28], we used three traps per site, placed at least $30 \mathrm{~m}$ apart and $50 \mathrm{~m}$ away from the mist nets to avoid interference. Fresh sticky liners and pheromone lures were used for each PNC generation. We recorded the mean and maximum numbers of PNC captured per trap per night. 


\subsubsection{PNC Availability-Black Light Traps}

To estimate the numbers and biomass of PNC moths relative to other insects that may serve as prey for bats, we used insects collected with black light traps as part of another study during year two of the present study [36]. We collected insect samples with black lights on 43 nights, 22 of which coincided with fecal collections. We deployed two black light traps (12-Watt fluorescent black lights; Bioquip Products, Inc.) in each site for four hours (22:00-02:00) in locations with minimal obstructions: $\geq 50 \mathrm{~m}$ from the habitat edge, $\geq 50 \mathrm{~m}$ from any mist net, and $\geq 85 \mathrm{~m}$ from each other. Insects were killed with strips of a solid insecticide (Dichlorvos, HotShot No-Pest Strip; Spectrum Brands, Inc., Middleton, WI, U.S.A.) and dried at $60^{\circ} \mathrm{C}$ until constant mass was achieved (3-5 days). We identified and counted PNC moths and all other insects to order and size category. We defined prey-sized insects to be 5-30 mm [45-47]. For each sample, we recorded the number of PNC moths per trap hour, and calculated the proportional PNC abundance and biomass relative to PNC-sized moths (5-20 $\mathrm{mm}$ body length), prey-sized moths $(5-30 \mathrm{~mm})$, all prey-sized insects $(5-30 \mathrm{~mm})$ and total insects (all sizes) for each capture night.

\subsection{Fecal Analysis}

\subsubsection{DNA Extraction}

Extraction methods are as in Brown et al. (2015), with minor modifications. DNA was extracted from all fecal material obtained from individual bats, for up to $70 \mathrm{mg}$ dried feces, using the "maximum yield" protocol provided with UltraClean Soil DNA Isolation Kits (MoBio Laboratories, Carlsbad, CA, U.S.A.), with incubation at $4{ }^{\circ} \mathrm{C}$ for at least one hour, rather than the recommended 5 minutes. A negative control of feces collected from a captive colony of big brown bats (Eptesicus fuscus) fed a non-moth diet was included in each batch of extractions.

\subsection{2. qPCR Analysis}

We used primers and a qPCR probe specific to PNC, i.e. Acnu COI F, Acnu COI R and Acnu COI probe [21], designed and tested using sequences derived from PNC moths collected in the study area. These primers yield $\sim 182 \mathrm{bp}$ of amplicon within the standard $658 \mathrm{bp}$ cytochrome $c$ oxidase I (COI) barcode region. All qPCR conditions follow those of Brown et al. (2015). Based on the size standards, the lower detection limit for the assays was 40 copies per reaction. All samples and controls were amplified in a single reaction in year one and in duplicate in year two. Due to unpredictable effects resulting from digestion, the presence of other prey in the diet, and PCR amplification biases, qPCR analysis from fecal samples provides only a semi-quantitative estimate of the specific prey consumed [20,48-50]. Samples were considered positive for PNC if the PNC COI gene amplified in at least one of two duplicate qPCRs. Frequency of occurrence was calculated nightly and overall for each species as the number of PNC positive samples divided by the total number of samples tested. Gene copy numbers were averaged over successful duplicate qPCRs (replicates testing negative for PNC were considered to have zero gene copies) and standardized in relation to dry mass of feces for each sample.

\subsubsection{Control for False Negatives}

To account for false negatives, we tested all fecal extractions with conserved/universal primers (LCO1490 and HCO2198; [51]) following the protocol in Brown et al. (2015). These primers amplify a $658 \mathrm{bp}$ fragment of the COI gene from a broad range of taxa confirming that a fecal extract includes amplifiable DNA, although the DNA could be that of the bat, and it is possible that prey DNA is too degraded for amplification. Samples that failed to produce product in two separate reactions were excluded from subsequent analyses. 


\subsection{Statistical Analyses}

We used RStudio (v. 0.97.551) and R version 3.0.2 [52] for all analyses. Summary statistics are presented as the mean \pm the standard error of the mean (SEM). To test factors explaining the occurrence (presence/absence) and quantity (average gene copies per gram) of PNC in bat diets, we used generalized linear mixed-effects models (GLMMs) and linear mixed-effects models (LMMs), respectively. We used 'date' as a random effect, which accounted for multiple bats captured on the

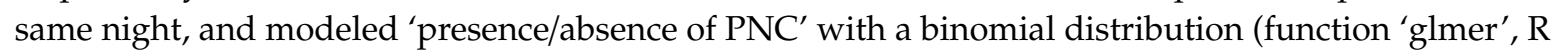
package lme4; [53]) and 'gene copies' (natural log transformed) with a Gaussian distribution (function 'Ime', R package nlme; [54]). We first tested for an effect of year $(2008,2009)$ and agroecosystem type (native groves, conventional orchards) on the two response variables using a likelihood ratio test (function 'anova', R Stats package); as there was no effect of either variable on 'presence/absence of PNC' (year: $\chi=1.05, P=0.306$; agroecosystem type: $\chi=2.22, P=0.136$ ), or on 'gene copies' (year: $\chi=$ $1.93, \mathrm{P}=0.165$; agroecosystem type: $\chi=2.04, \mathrm{P}=0.154)$, we pooled all data together.

We tested for differences in PNC consumption among the bats captured by fitting a null model and suite of 20 alternative models for each response variable with biologically relevant combinations of fixed effects: 'bat species', 'time of capture' (evening or morning), 'PNC generation' in which the bat was captured (1,2 or 3), and 'individual bat characteristics' ('sex', 'age', 'body condition index' [body mass/forearm length; BCI]) (Table A1). We limited each model to a maximum of three variables to avoid model over-fit and loss of statistical power [55]. We used second order Akaike's Information Criterion (AICc), for small samples sizes, and Akaike weights $\left(\omega_{\mathrm{i}}\right)$, to determine the relative support for each model [56]. If these models had equivalent support $(\leq 2 \Delta \mathrm{AIC})$, we selected the model with the fewest parameters and calculated evidence ratios (ratios of Akaike weights [ER]), which indicate the likelihood of one model versus another [56]. Parameters were estimated using maximum likelihood (ML) and Laplace approximation for GLMMs, and restricted maximum likelihood (REML) for LMMs; ML was used for all model comparisons [56]. We calculated the overall effects of categorical variables using a likelihood ratio test between the model and a nested model without the variable of interest, and post-hoc, pairwise comparisons among levels of significant categorical variables using Tukey HSD tests for multiple comparisons (function 'glht', R package Multcomp; [57]).

We then followed the same general strategy to test the effect of nightly PNC availability on temporal consumption of PNC. We used our best model from our initial suite of models to assess if any PNC variables significantly improved the model additively or singularly. To reduce colinearity, we only included predictor variables in the same model that had correlation coefficients $<|0.5|$ (Spearman rank correlation matrices; [58,59]); hence, because measures of PNC availability were highly correlated (Spearman rank, $r>0.95$ ), we only included one PNC variable in each model. We first assessed measures of PNC availability as measured with pheromone traps: Thus, 'mean PNC counts per night', 'mean PNC counts from previous night', 'maximum nightly PNC count for any trap in study area' (Appendix A). Finally, to assess measures of PNC availability relative to other potential prey items in the area, we used a reduced data set comprising only nights when we had both samples from black light traps and bat feces (22 nights, 177 bats; Table A1).

\section{Results}

\subsection{PNC Detection}

We tested fecal samples from 397 individual bats, of which 29 (7.3\%) did not produce product with the universal COI primers, and were removed from further analyses (Appendix A). The remaining 368 samples represented five species of bats: Eastern red $(n=69)$, cave myotis $(n=119)$, evening $(n$ $=87)$, tri-colored $(n=7)$ and Brazilian free-tailed $(n=86)$ bats captured during 51 nights in native pecan groves ( 246 bats; 38 nights) and conventional pecan orchards (122 bats; 13 nights). From one to 32 samples (average $=7.22 \pm 0.92$ ) were analyzed from any given night based on the number of bats captured. 
The PNC-specific primers produced product in samples from at least one bat for all five species, with an overall frequency of occurrence of $9.0 \%$ (33 of 368 samples) across all individuals. We documented PNC consumption by bats captured in both native and conventional pecan agroecosystems.

We detected the highest frequency of occurrence of PNC in samples from eastern red bats $(23.2 \%)$ followed by tri-colored bats (14.3\%), cave myotis (7.6\%), Brazilian free-tailed bats (5.8\%) and evening bats (2.3\%; Figure 3a); however, sample sizes for captured bats varied nightly and over the season, and consumption rates varied accordingly (Table A1). Due to the small sample size for tri-colored bats $(n=7)$, we excluded this species from further analyses. The most parsimonious model predicting the likelihood of occurrence of PNC in the diet included 'bat species' alone $\left(\omega_{i}=0.15, \chi^{2}=17.34, \mathrm{df}=\right.$ $3, p<0.001$; Table 1). After adjusting for multiple comparisons, eastern red bats had a significantly higher likelihood of having consumed PNC than cave myotis $(\beta=1.30 \pm 0.50, p=0.042)$ and evening bats $(\beta=2.65 \pm 0.80, p=0.005)$, but not Brazilian free-tailed bats $(\beta=1.53 \pm 0.63, p=0.069)$. Pairwise comparisons between bat species other than between eastern red bats and all other species showed no significant differences.
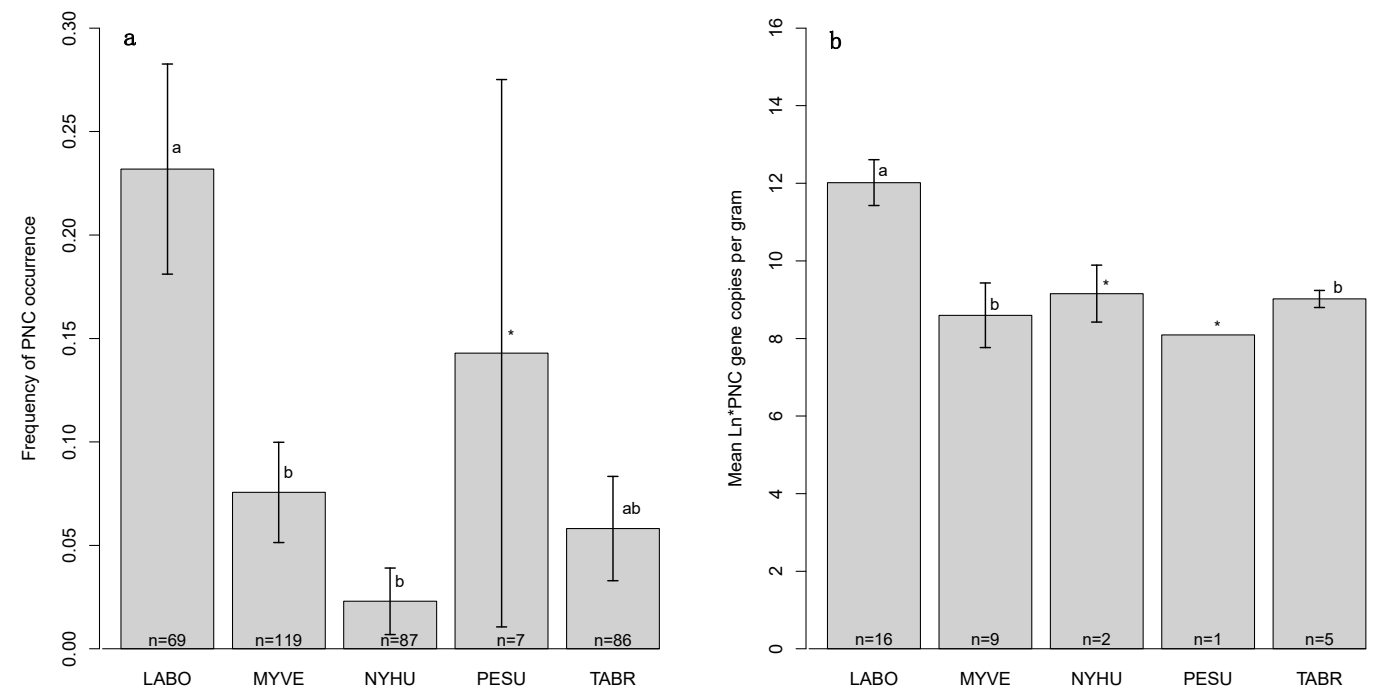

Figure 3. Consumption of pecan nut casebearer (PNC) moths, Acrobasis nuxvorella, by five bat species as detected with a quantitative (real-time) polymerase chain reaction (qPCR) of fecal DNA: (a) Frequency of occurrence (percentage of fecal samples from bats of each species from which the PNC gene marker was amplified in at least one qPCR), and (b) gene copies per gram of feces (ln-transformed) for those samples testing positive for PNC. Letters depict significant differences between bat species $(\alpha=$ 0.05). Asterisks $\left(^{*}\right)$ indicate groups that were removed from analyses due to low sample size. Species abbreviations: $\mathrm{LABO}=$ Lasiurus borealis, $\mathrm{MYVE}=$ Myotis velifer, $\mathrm{NYHU}=$ Nycticeius humeralis, $\mathrm{PESU}=$ Perimyotis subflavus, TABR = Tadarida brasiliensis.

Eastern red bats that were positive for PNC also had higher average PNC gene copies per gram of feces than all other bat species tested (eastern red bats, $1.99 \times 10^{6} \pm 1.33 \times 10^{6}, \mathrm{n}=16$; cave myotis, 9.54 $\times 10^{4} \pm 6.80 \times 10^{4}, \mathrm{n}=9, p<0.001$; Brazilian free-tailed bats, $9.05 \times 10^{3} \pm 1.83 \times 10^{3}, \mathrm{n}=5, p=0.015$; Table 1 ; Figure $3 \mathrm{~b}$ ). Gene copy numbers did not significantly differ between cave myotis and Brazilian free-tailed bats. As only two samples of evening bats were positive for PNC $\left(1.21 \times 10^{4} \pm 7.59 \times 10^{3}\right)$ and one sample for tri-colored bats $\left(3.27 \times 10^{3}\right)$, they were not included in further analyses of gene copies. The model with the lowest AICc included only 'bat species' $\left(\chi^{2}=8.78, p=0.012\right.$; Table 1$)$. The model with 'time of capture' was considered equally plausible and indicated that, in contrast to what we had predicted, bats captured in the evening (20:00-01:00) had higher gene copies than bats captured in the morning (101-600 h) $(\beta=2.21 \pm 0.80, p=0.016)$. 'PNC generation' was included in an alternate model receiving lower support, indicating an increase in gene copies across the season $(\beta=1.49 \pm 0.63$, $p=0.035)$. 
Table 1. Best models explaining the presence or absence of the PNC marker (generalized linear mixed-effects model, GLMM) and number of PNC gene copies per gram (linear mixed-effects model, LMM) in bat guano.

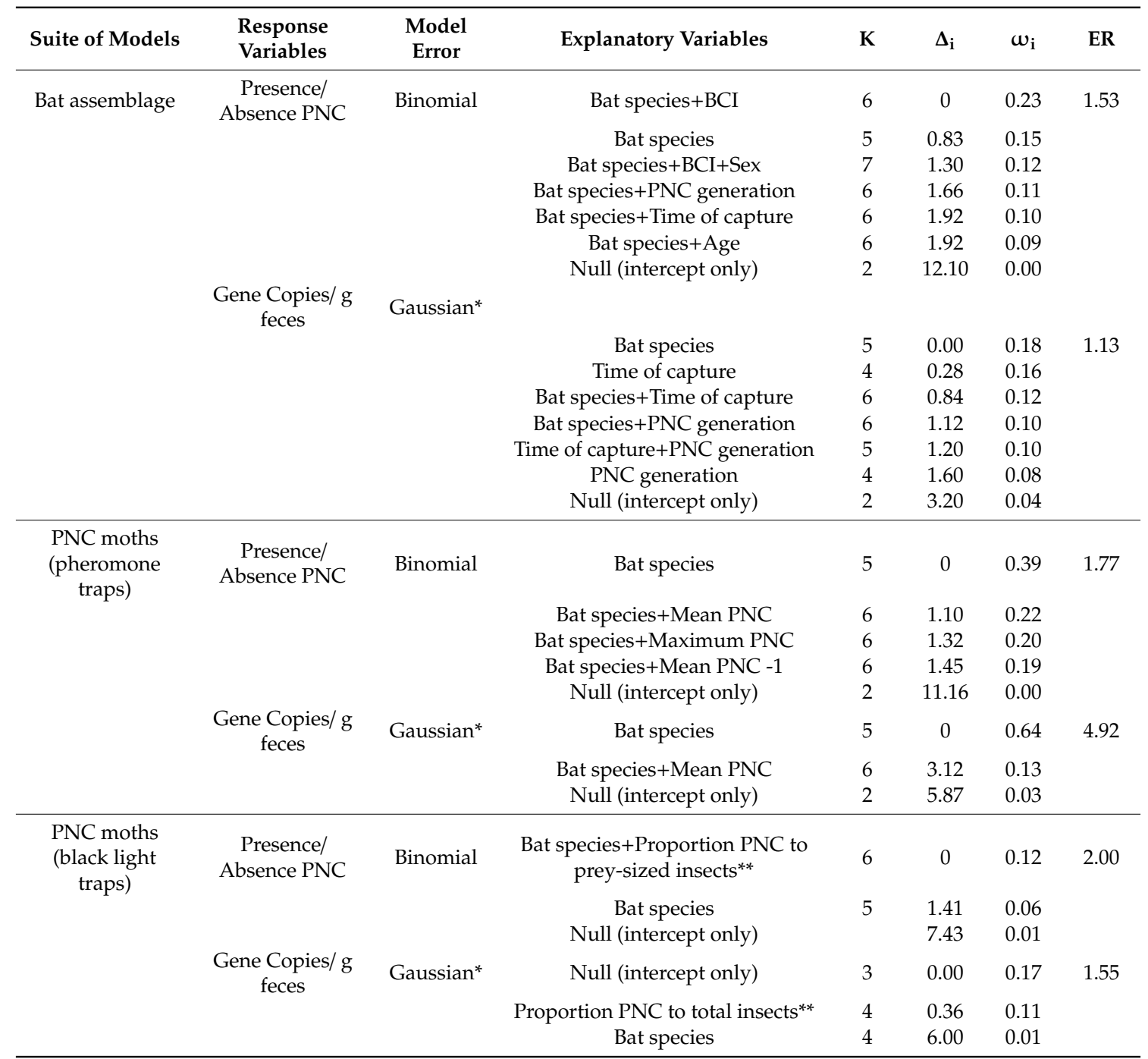

Note: For each full (all nights) and reduced (only nights with black light trap samples) dataset, the models are ranked by $\Delta_{\mathrm{ii}}$ (difference between each alternative model and the model with the lowest Akaike Information Criterion (AIC) or second order Akaike Information Criterion (AICc) score) and $\omega_{i}$ (Akaike weights). All models within $2 \Delta$ AIC are listed unless otherwise noted, and models in bold are considered the best model. PNC $=$ Pecan nut casebearer moth (Acrobrasis nuxvorella). $\mathrm{BCI}=$ Body Condition Index. ${ }^{*}$ Ln-transformation. ${ }^{* *}$ Only best measure of proportional PNC listed here due to space constraints, but all were included within $2 \triangle$ AIC of top model.

\subsection{Temporal Predator-Prey Patterns}

\subsubsection{Pheromone Traps}

Pheromone trap captures of PNC moths peaked sharply several times within native pecan groves and conventional pecan orchards (Figure 4a). In year one, a large PNC emergence was detected between 29 April-25 May 2008; Figure 4a). Fecal samples positive for PNC were detected only after this PNC peak had subsided; however, our bat captures during the period that overlapped with the PNC emergence (April-May) were low (14 of 47 total samples for year one), and our sampling of PNC and bats did not extend beyond mid-June. In year two, pheromone traps detected three distinct generations of PNC moths, with peak moth captures decreasing over the season. PNC consumption by bats occurred in each of the three PNC generations, with percent of positive samples varying nightly (range: 4.5 to $50 \%$; Figure $4 \mathrm{a}$ ). The overall frequency of PNC consumption by bats appears to be higher in the second and third generations 
than within the first (Figure 4a; Table S1); however, because sample sizes varied considerably across the season (e.g. greater numbers of eastern red bats later in the season), species composition and temporal effects are partially confounded. Similarly, gene copies per gram of feces varied temporally and by species, with the highest values detected in eastern red bats during the third PNC generation (Figure 4b). Despite PNC consumption by bats across the season, no measure of nightly PNC abundance estimated from pheromone traps significantly improved our best model of PNC presence in fecal samples or the number of gene copies detected in positive fecal samples (Table 1).
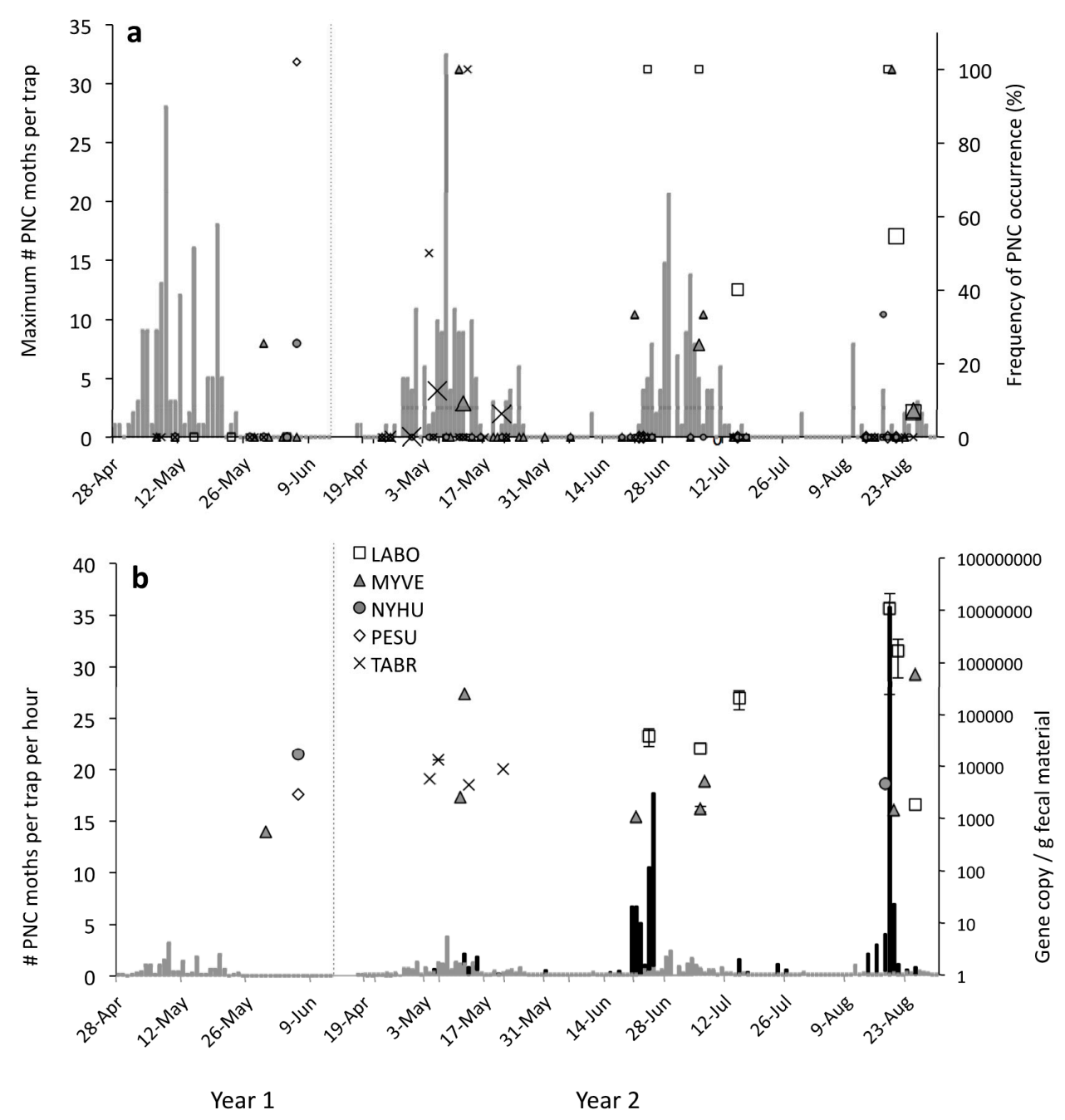

Figure 4. Nightly consumption of pecan nut casebearer (PNC) moths, Acrobasis nuxvorella, by bats relative to seasonal activity of male PNC moths captured in pecan agroecosytems in Texas (Year 1 = 2008; Year 2 = 2009). a) 'Frequency of PNC occurrence'. Maximum moth count per pheromone trap across sites (solid gray bars; primary axis) and percent of fecal samples positive for the PNC marker (symbols; secondary axis) for each species per night. Relative size of symbols corresponds to the number of samples tested per night, ranging from 1 to 32 (mean $7.4 \pm 1.0$ samples per night for all bat species). b) ‘PNC Gene copies'. Number of PNC moths captured with pheromone traps (gray bars) and with black light traps (black bars) scaled by the hour to account for differences in the number of trap hours (primary axis). Black light samples were only collected in year two. Mean gene copies per gram of feces \pm SEM for samples positive for PNC for each bat species per night (secondary axis-logarithmic scale); symbols with no error bars represent single samples. Species abbreviations: $\mathrm{LABO}=$ Lasiurus borealis, $\mathrm{MYVE}=$ Myotis velifer, $\mathrm{NYHU}=$ Nycticeius humeralis, $\mathrm{PESU}=$ Perimyotis subflavus, TABR = Tadarida brasiliensis. 


\subsubsection{Black-Light Traps}

Numbers of PNC moths per trap-hour were higher in black light traps than pheromone traps in the second and third PNC generations (Figure $4 \mathrm{~b}$ ). There was no correlation between black light and pheromone trap catches (Spearman rank, $r_{\mathrm{s}}=0.03$ ), and estimates of PNC abundance from black light and pheromone traps exhibited nearly opposite seasonal patterns. The proportional abundance and biomass of PNC moths relative to all available prey varied by sample night (Figure S1).

Among all PNC-sized moths (5-20 mm), PNC abundance and biomass were low, averaging 4.12 $\pm 1.22 \%(0-22.63 \%)$ and $4.74 \pm 1.55 \%(0-31.67 \%)$, respectively. Among prey-sized insects of all orders, PNC represented only $2.34 \pm 0.82 \%(0-17.85 \%)$ abundance and $1.09 \pm 0.35 \%(0-7.41 \%)$ biomass. Using a reduced data set comprising only nights with samples from both black light traps and bat guano (22 nights, 177 bats), we found that all models containing measures of PNC abundance and biomass outperformed the model with 'bat species' alone when predicting PNC presence in bat guano; however, all models were within $2 \triangle \mathrm{AICc}$, and were thus considered equally plausible (Table 1 ). The model with the lowest AICc included 'bat species' $\left(\chi^{2}=12.02, p=0.007\right)$ and 'proportional abundance of PNC relative to total prey-sized insects' $\left(\chi^{2}=3.46, p=0.059\right.$; Table 1$)$. No additional variables improved the null model in predicting the number of gene copies; however all measures of PNC availability were within $2 \triangle$ AICc of the null model.

\section{Discussion}

Two general approaches to estimate the value of bats in pest suppression are outlined by Boyles et al. (2013) [60]: 1) Single species impacts as measured or modeled based on the biology of the bats, pests and crops $[9,61]$ and 2) community level impacts measured from predator exclusion experiments $[13,62,63]$. While both are valuable, the latter approach does not distinguish species-specific effects. Here we provide evidence of different rates of predation on an economically important pest of pecans by a bat assemblage over time, suggesting that contributions to pest suppression differ by bat species. Further, compared to estimates obtained by sampling a centralized roost of Brazilian free-tailed bats [21], our sampling of multiple species that fly below the canopy allows us to refine our estimates of PNC consumption for bats within pecan orchards, by bat species and across PNC generations.

Within the assemblage of bats that we investigated, our results suggest that eastern red bats are the primary bat predators of PNC moths, with frequencies of PNC consumption two to ten times greater, and average PNC gene copy numbers two to three orders of magnitude higher, than for the other bat species examined. Eastern red bats roost in the foliage of trees, often in riparian forests $[64,65]$. Within our study area, eastern red bats roost predominantly in pecan trees [36], often adjacent to pecan nut clusters where PNC are most active (Figure 1). Further, these bats generally forage near the canopy in forests [66,67], and within our study area we captured eastern red bats more frequently in pecan orchards than in surrounding mesquite-juniper woodlands [36]. Thus we suggest that higher consumption of PNC by eastern red bats occurs due to their roosting and foraging behaviors in cluttered environments, which lead them to more frequent encounters with PNC moths in the pecan canopy than the other bat species. Eastern red bats may also target and consume PNC because these moths are in the size range of the bats' preferred prey. This species frequently preys on moths, including those with tympanate ears [39,41,68], and on moths similar in size to PNC [47].

Similarly, we suspect that the lower consumption of PNC by Brazilian free-tailed bats and cave myotis is due to their foraging behaviors, resulting in little interaction with PNC moths. Brazilian free-tailed bats have wings adapted for flight at higher altitudes (15-900 m), in open areas and over long distances [35,37], putting them in closer contact with stronger-flying insects above the canopy, such as corn earworm moths (Helicoverpa zea) [16,20], rather than PNC moths within the pecan canopy. Our estimates of PNC consumption are higher in samples collected from Brazilian free-tailed bats captured in mist-nets $(5.8 \pm 2.5 \%)$ than from samples collected under roosts within pecan orchards $(1.4 \%$; [21]), suggesting that many of the bats in those roosts forage above or outside pecan orchards beyond the typical range of PNC moths. In contrast, cave myotis have shorter, wider wings that are more adapted 
to cluttered environments [69], and often fly within the canopy [70], thus we would expect a greater consumption of PNC. However, we previously documented no preference by cave myotis, or Brazilian free-tailed bats, for pecan orchards and groves when compared to the surrounding landscape [36], suggesting that these species may spend less time foraging in areas where PNC are most active. Because PNC moths are in the range of common prey sizes reported for both species $[35,38,46,71]$, we would expect these moths be consumed if encountered.

In contrast to expectations based on their wing morphology and typical roosting and foraging habitat, evening bats have the lowest frequency of PNC consumption compared to all other species examined. We previously found that evening bats roost in cavities in pecan trees and are captured more frequently in pecan groves and orchards than in adjacent mesquite-juniper woodlands [36]. This species is known to forage in riparian areas, along the edges of forests and just above and below tree crowns $[66,72,73]$. Thus, it seems likely that evening bats would encounter PNC moths while foraging. However, because beetles appear to be a primary prey source for evening bats $[39,40,74]$, low PNC consumption by this species may reflect dietary preference, rather than any lack of opportunity for predation. Due to our limited sample size for tri-colored bats, we are unable to draw conclusions about the degree of PNC consumption by this species.

\section{Temporal Predator-Prey Patterns}

Our documentation of PNC consumption by multiple species of bats during all three peaks of PNC moth emergence (in year two) suggests predation pressure by bats across the entire season of PNC moth activity. Seasonal variation in PNC consumption by bats, the positive association with PNC abundance (as measured with black light traps) and the relatively low occurrence of PNC found in our samples suggests these bats are generalists, preying opportunistically on PNC moths at times of peak abundance. This ability to persist within the agroecosystem and respond to episodic pest eruptions increases the effectiveness of generalist predators at suppressing insects in agroecosystems [3]. However, we do not have evidence that the rate of predation we observe is sufficient to suppress PNC populations or reduce damage to pecans. Higher PNC gene copies in the feces of bats captured in the evening than bats captured in the morning contradicts our expectations based on male moth activity patterns in other studies. Although male PNC moths are responsive to pheromones during the entire scotophase (22:00-05:00), the majority of trap captures and peak female mate calling typically occurs between 00:00 and 04:00 [25,75]. Our results suggest that PNC flight activity may be higher in the evening hours than that indicated by pheromone traps. It is also possible that female PNC moths, which are not attracted to pheromone traps, are more active and available to bats during the evening hours; however, we are unable to test this with our data and warrants further research.

The discrepancies between PNC captures in pheromone traps versus black light traps and the occurrence of PNC in the bat diets suggest that black-light traps better sample PNC moth availability to the bats. Similar to our findings, pheromone trap counts do not correspond to consumption patterns of migratory moths in the diet of Brazilian free-tailed bats [16]. Krauel et al. (2018) suggest that this is due to the local, ground level sampling of the pheromone traps versus the long-range, aerial sampling of the bats. Pheromone traps also attract only reproductively-active male moths, whereas black light traps attract both males and females, with no apparent sex-bias [76]. In several species of moths within the family Pyralidae, to which the PNC belongs, the efficacy of pheromone traps decreases with increased competition by females calling for mates (e.g. [77-79]). Earlier black light trapping [76] shows that PNC density increases, and male-female ratios decrease, with each generation; this seasonal shift in sex ratios may explain the patterns in our pheromone traps, with higher captures in the first generation when competition for females is high, and lower captures when females outnumber males in the third generation. Thus, pheromone traps may not accurately track PNC availability to bats because changes in female density and mate calling influence trap success.

According to our estimates from black light traps, on most nights PNC moths represent $<5 \%$ of the prey available to bats, but are a significant prey source on several nights when they peak in abundance 
(e.g. $17.9 \%$ of prey sized insects and $31.7 \%$ biomass of PNC-sized moths, Figure S1). Our results indicate that the abundance of PNC moths relative to other available, prey-sized insects influences the likelihood of PNC consumption by bats, suggesting that the frequency with which PNC moths are encountered during foraging may be more important than the biomass, which also takes into account the size and possible energetic reward of the prey.

As might be expected for a generalist predator [3], we suggest that bats do not target PNC moths, but forage on them opportunistically when they are in high abundance relative to other available prey.

\section{Conclusions: Conservation and Management Implications}

Both in frequency of occurrence (34.4\%) and gene copies $\left(2.41 \times 10^{7} \pm 6.40 \times 10^{7}\right.$ per gram), the level of PNC consumption for eastern red bats is comparable to previous findings of the consumption of corn earworm moths (Heliocoverpa zea) by Brazilian free-tailed bats [20], suggesting that the predation of PNC moths by eastern red bats may provide similar ecosystem services as Brazilian free-tailed bats do for H. zea [9,61]. Although Brazilian free-tailed bats have a much higher population density than eastern red bats, and can have large impacts upon pests in open agricultural areas [61], eastern red bats may be more important predators in cluttered habitats. Documentation of PNC consumption by bats does not indicate control of PNC, but provides important initial evidence and is the first step in estimating the value of this potential ecosystem service provided by bats [60]. Many native groves and organic orchards do not use any treatments against insect pests and rely solely on natural predators. Predation on moths by bats occurs before other natural enemies attack eggs and larvae, and before pesticides targeting larvae are used in conventional orchards. Thus, bats may act as the first line of defense in reducing crop damage by PNC. Further research is needed to investigate the magnitude of PNC suppression by bats, and how this may be influenced by various factors including interactions with other natural enemies in the system.

Because PNC moths are small, episodic and comprise a relatively low proportion of total prey availability in the system, predation pressure by multiple species across periods of heightened PNC activity may be necessary for effective pest suppression. Habitat conservation measures that encourage bat abundance, particularly for eastern red bats, may increase predation pressure on PNC moths. Installing artificial roosting structures for bats is one strategy to attract bats to agroecosystems (Boyles et al. 2013) [60], but this will not be effective for tree bats that roost in foliage [80]. Instead, reducing branch cropping, and planting trees in tree gaps, may increase roost availability. Broadcasting conspecific feeding buzzes or social calls also may attract bats $[60,81]$, but may not be equally effective across species. Due to the suspected adverse effects of chemical pesticides applied to trees where bats roost in foliage and the areas in which they forage $[82,83]$, we recommend that some areas be left unsprayed for bats to have alternate foraging and roosting sites during such management events.

Studies of pest consumption by bats in agriculture have primarily focused on bat species located in accessible colonies, such as caves or bat houses, that enable the capture and convenient sampling of guano (e.g., $[15,16,20,21])$. Our finding that the consumption of PNC occurs primarily by a solitary tree roosting bat, highlights a need to consider non-colonial species dispersed across the landscape, and those capable of foraging in cluttered habitats when assessing pest suppression services. Considering the diet of only one common, or easily captured species, limits our ability to accurately document the consumption of destructive pests by bats in agroecosystems, particularly in more complex agroforestry or tree crop systems. To assess and ultimately enhance pest suppression services, it is imperative to recognize the roles of different species in the assemblages of predators within agroecosystems.

Supplementary Materials: The following are available online at http://www.mdpi.com/2071-1050/11/22/6365/s1, Table S1: Frequency of PNC occurrence (\%) in bat fecal samples across PNC generation and bat species, Figure S1: Relationships between the proportional biomass and abundance of PNC moths in relation to total prey availability. Table S2: Dataset and description of variables used in analyses.

Author Contributions: Conceptualization, E.C.B.d.T., V.A.B., T.H.K. and G.F.M.; methodology, E.C.B.d.T., V.A.B., T.H.K. and G.F.M.; validation, V.A.B.; formal analysis, E.C.B.d.T.; investigation, E.C.B.d.T.; resources, T.H.K., 
G.F.M.; data curation, E.C.B.d.T. and V.A.B.; writing—original draft preparation, E.C.B.d.T.; writing-review and editing, V.A.B., G.F.M.; visualization, E.C.B.d.T.; supervision, V.A.B., G.F.M. and T.H.K.; project administration, E.C.B.d.T.; funding acquisition, E.C.B.d.T.

Funding: This research was funded by the National Science Foundation Graduate Research Fellowship Program, Bat Conservation International Student research grant, and American Society of Mammalogists grants-in-aid of research awarded to the corresponding author (E.C.B.).

Acknowledgments: We thank J. and J. Byrd, D. Leonard, C. and K. Bessent, W. Ellis, J. and S. Conyers, and G. and L. Thompson for access to sites and valuable input. We also thank B. Yuen, K. Lear, L. Snyder, D. Katz, J. Gardner, L. Zheng, G. Kanner, J. J. Torrez, C. Lupoli, J. Collins, T. Etheridge and V. Richards for assistance in the field and $\mathrm{lab}$, and M. Sorenson and A. Wilder for discussions and reviews of the manuscript.

Conflicts of Interest: The authors declare no conflict of interest. The funders had no role in the design of the study; in the collection, analyses, or interpretation of data; in the writing of the manuscript, or in the decision to publish the results.

\section{Appendix A}

Table A1. Explanatory variables tested with mixed-effects models to predict presence/absence of PNC and gene copies per gram in fecal samples of individual bats captured in pecan agroecosystems in Texas $(2008,2009)$.

\begin{tabular}{|c|c|c|c|c|}
\hline Explanatory Variable & Type & Description & \multicolumn{2}{|c|}{ Sample Size } \\
\hline Study Year & Factor & Year one (2008) & 47 & 10 \\
\hline \multirow[t]{2}{*}{ Agroecosystem type } & Factor & Native pecan groves & 246 & 38 \\
\hline & & Conventional pecan orchards & 122 & 13 \\
\hline \multirow[t]{4}{*}{ Bat Species } & Factor & Eastern red bat, Lasiurus borealis & 69 & 19 \\
\hline & & Evening bat, Nycticeius humeralis & 87 & 33 \\
\hline & & Tri-colored bat, Perimyotis subflavus & 7 & 6 \\
\hline & & Brazilian free-tailed bat, Tadarida brasiliensis & 86 & 19 \\
\hline \multicolumn{5}{|l|}{ Individuals Bat Characteristics } \\
\hline \multirow[t]{2}{*}{ Age } & Factor & Juvenile & 116 & 22 \\
\hline & & Adult & 250 & 50 \\
\hline \multirow[t]{2}{*}{ Time of Capture } & Factor & Evening (2000-0100 h) & 192 & 44 \\
\hline & & Morning $(0101-0600 \mathrm{~h})$ & 176 & 35 \\
\hline \multicolumn{5}{|c|}{ PNC Availability (PNC moth counts from pheromone traps) } \\
\hline Mean PNC & Continuous & Mean nightly moth counts per trap & 347 & 44 \\
\hline Mean PNC-1 & Continuous & $\begin{array}{l}\text { Mean nightly moth counts per trap from } \\
\text { night prior to night of bat capture }\end{array}$ & 347 & 44 \\
\hline Maximum PNC & Integer & $\begin{array}{l}\text { Maximum nightly moth count recorded for } \\
\text { any trap in study area }\end{array}$ & 347 & 44 \\
\hline PNC Generation & Factor & PNC generation one, two or three & 368 & 51 \\
\hline \multicolumn{5}{|c|}{ PNC Availability (PNC moth counts and biomass from black light traps) } \\
\hline Total PNC Abundance & Continuous & PNC abundance per trap hour & 177 & 22 \\
\hline Proportional Abundance of total insects & Proportion & No. PNC / all insects (all sizes) & 177 & 22 \\
\hline Proportional Biomass of total insects & Proportion & PNC biomass / all insects (all sizes) & 177 & 22 \\
\hline
\end{tabular}

Note: Sample sizes associated with each variable are listed in terms of the number of bats and the number of nights corresponding to fecal samples. After elimination of false negatives $(n=29), 368$ samples from individual bats spanning 51 nights were included in analyses. 


\section{References}

1. Costamagna, A.C.; Landis, D.A. Predators exert top-down control of soybean aphid across a gradient of agricultural management systems. Ecol. Appl. Publ. Ecol. Soc. Am. 2006, 16, 1619-1628. [CrossRef]

2. Naylor, R.L.; Ehrlich, P.R. Natural pest control services and agriculture. In Nature's Services; Daily, G.C., Ed.; Island Press: Washington, DC, USA, 1997; pp. 151-176.

3. Symondson, W.O.C.; Sunderland, K.D.; Greenstone, M.H. Can generalist predators be effective biocontrol agents? Annu. Rev. Entomol. 2002, 47, 561-594. [CrossRef] [PubMed]

4. Hawkins, B.A.; Mills, N.J.; Jervis, M.A.; Price, P.W. Is the biological control of insects a natural phenomenon? Oikos 1999, 86, 493-506. [CrossRef]

5. Landis, D.A.; van der Werf, W. Early season predation impacts the establishment of aphids and spread of beet yellows virus in sugar beet. Entomophaga 1997, 42, 499-516. [CrossRef]

6. Wiedenmann, R.N.; Smith, J.W. Attributes of natural enemies in ephemeral crop habitats. Biol. Control 1997, 10, 16-22. [CrossRef]

7. Cook, S.P.; Smith, H.R.; Hain, F.P.; Hastings, F.L. Predation of gypsy moth (Lepidoptera: Lymantriidae) pupae by invertebrates at low small mammal population densities. Environ. Entomol. 1995, 24, 1234-1238. [CrossRef]

8. Ehler, L.E. Invasion biology and biological control. Biol. Control 1998, 13, 127-133. [CrossRef]

9. Federico, P.; Hallam, T.G.; McCracken, G.F.; Purucker, S.T.; Grant, W.E.; Correa-Sandoval, A.N.; Westbrook, J.K.; Medellin, R.A.; Cleveland, C.J.; Sansone, C.G.; et al. Brazilian free-tailed bats as insect pest regulators in transgenic and conventional cotton crops. Ecol. Appl. 2008, 18, 826-837. [CrossRef]

10. Dainese, M.; Schneider, G.; Krauss, J.; Steffan-Dewenter, I. Complementarity among natural enemies enhances pest suppression. Sci. Rep. 2017, 7, 8172. [CrossRef]

11. Kunz, T.H.; Braun de Torrez, E.C.; Bauer, D.M.; Lobova, T.; Fleming, T.H. Ecosystem services provided by bats. Ann. N. Y. Acad. Sci. 2011, 1223, 1-38. [CrossRef]

12. Ghanem, S.J.; Voigt, C.C. Increasing Awareness of Ecosystem Services Provided by Bats. Adv. Stud. Behav. 2012, 44, 279-302.

13. Maine, J.J.; Boyles, J.G. Bats initiate vital agroecological interactions in corn. Proc. Natl. Acad. Sci. USA 2015, 112, 12438-12443. [CrossRef] [PubMed]

14. Russo, D.; Bosso, L.; Ancillotto, L. Novel perspectives on bat insectivory highlight the value of this ecosystem service in farmland_Research frontiers and management implications. Agric. Ecosyst. Environ. 2018, 266, 31-38. [CrossRef]

15. Aizpurua, O.; Budinski, I.; Georgiakakis, P.; Gopalakrishnan, S.; Ibañez, C.; Mata, V.; Rebelo, H.; Russo, D.; Szodoray-Parádi, F.; Zhelyazkova, V.; et al. Agriculture shapes the trophic niche of a bat preying on multiple pest arthropods across Europe: Evidence from DNA metabarcoding. Mol. Ecol. 2018, 27, 815-825. [CrossRef] [PubMed]

16. Krauel, J.J.; Brown, V.A.; Westbrook, J.K.; McCracken, G.F. Predator-prey interaction reveals local effects of high-altitude insect migration. Oecologia 2018, 186, 49-58. [CrossRef]

17. Clare, E.L. Molecular detection of trophic interactions: Emerging trends, distinct advantages, significant considerations and conservation applications. Evol. Appl. 2014, 7, 1144-1157. [CrossRef]

18. Vesterinen, E.J.; Ruokolainen, L.; Wahlberg, N.; Peña, C.; Roslin, T.; Laine, V.N.; Vasko, V.; Sääksjärvi, I.E.; Norrdahl, K.; Lilley, T.M. What you need is what you eat? Prey selection by the bat Myotis daubentonii. Mol. Ecol. 2016, 25, 1581-1594. [CrossRef]

19. Maas, B.; Clough, Y.; Tscharntke, T. Bats and birds increase crop yield in tropical agroforestry landscapes. Ecol. Lett. 2013, 16, 1480-1487. [CrossRef]

20. McCracken, G.F.; Westbrook, J.K.; Brown, V.A.; Eldridge, M.; Federico, P.; Kunz, T.H. Bats Track and Exploit Changes in Insect Pest Populations. PLoS ONE 2012, 7, e43839. [CrossRef]

21. Brown, V.A.; Braun de Torrez, E.C.; McCracken, G.F. Crop pests eaten by bats in organic pecan orchards. Crop Prot. 2015, 67, 66-71. [CrossRef]

22. Kremen, C.; Williams, N.; Aizen, M.; Gemmill-Herren, B.; LeBuhn, G.; Minckley, R.; Packer, L.; Potts, S.; Roulston, T.; Steffan-Dewenter, I. Pollination and other ecosystem services produced by mobile organisms: A conceptual framework for the effects of land-use change. Ecol. Lett. 2007, 10, 299-314. [CrossRef] [PubMed] 
23. Maas, B.; Karp, D.S.; Bumrungsri, S.; Kevin Darras, D.G.; Huang, J.C.C.; Lindell, C.A.; Maine, J.J.; Mestre, L.; Michel, N.L.; Morrison, E.B.; et al. Bird and bat predation services in tropical forests and agroforestry landscapes. Biol. Rev. 2016, 91, 1081-1101. [CrossRef] [PubMed]

24. Harris, M.K. Integrated pest management of pecans. Annu. Rev. Entomol. 1983, 28, 291-318. [CrossRef]

25. Stevenson, D.E.; Harris, M.K. Determining circadian response of adult male Acrobasis nuxvorella (Lepidoptera: Pyralidae) to synthetic sex attractant pheromone through time-segregated trapping with a new clockwork timing trap. Environ. Entomol. 2009, 38, 1690-1696. [CrossRef]

26. Hartfield, E.A.; Harris, M.K.; Medina, R.F. Population structure of the pecan nut casebearer Acrobasis nuxvorella throughout its geographical distribution. Agric. For. Entomol. 2011, 14, 119-125. [CrossRef]

27. Bilsing, S.W. The life history and control of the pecan nut casebearer (Acrobasis caryae). Tex. Agric. Exp. Stn. Bull. 1926, 328, 1-77.

28. Harris, M.K.; Millar, J.G.; Knutson, A.E. Pecan Nut Casebearer (Lepidoptera: Pyralidae) sex pheromone used to monitor phenology and estimate effective range of traps. J. Econ. Entomol. 1997, 90, 983-987. [CrossRef]

29. Bilsing, S.W. Studies on the biology of the pecan nut casebearer, (Acrobasis caryae). Tex. Agric. Exp. Stn. Bull. 1927, 347, 1-71.

30. Aguirre, L.A.; Tucuch, M.; Harris, M.K. Oviposition and nut entry behavior of the pecan nut casebearer Acrobasis nuxvorella nuenzig. Southwest. Entomol. 1995, 20, 447-451.

31. Neunzig, H.H. Taxonomy of Acrobasis larvae in eastern North America (Lepidoptera: Pyralidae). USDA Tech. Bull. 1972, 1457, 1-158.

32. Ring, D.R.; Harris, M.K. Nut entry by first summer generation pecan nut casebearer. Southwest. Entomol. 1984, 9, 13-21.

33. Ring, D.R.; Harris, M.K.; Payne, J.A. Sequential sampling plan for integrated pest management of pecan nut casebearer (Lepidoptera: Pyralidae). J. Econ. Entomol. 1989, 82, 906-909. [CrossRef]

34. McCracken, G.F.; Safi, K.; Kunz, T.H.; Dechmann, D.K.N.; Swartz, S.M.; Wikelski, M. Airplane tracking documents the fastest flight speeds recorded for bats. R. Soc. Open Sci. 2016, 3, 160398. [CrossRef] [PubMed]

35. McCracken, G.F.; Gillam, E.H.; Westbrook, J.K.; Lee, Y.-F.; Jensen, M.L.; Balsley, B.B. Brazilian free-tailed bats (Tadarida brasiliensis: Molossidae, Chiroptera) at high altitude: Links to migratory insect populations. Integr. Comp. Biol. 2008, 48, 107-118. [CrossRef] [PubMed]

36. Braun de Torrez, E.C. Bats, Insects and Pecans: Habitat Use and Ecosystem Services of Insectivorous Bats in a Pecan Agroecosystem in Central Texas. Ph.D. Thesis, Boston University, Boston, MA, USA, 2014.

37. Ammerman, L.K.; Hice, C.L.; Schmidly, D.J. Bats of Texas; Texas A\&M University Press: College Station, TX, USA, 2012; p. 305.

38. Hayward, B.J. The natural history of the cave bat Myotis velifer. West. N. M. Univ. Res. Sci. 1970, 1, 1-74.

39. Cravens, Z.M.; Brown, V.A.; Divoll, T.J.; Boyles, J.G. Illuminating prey selection in an insectivorous bat community exposed to artificial light at night. J. Appl. Ecol. 2017, 55, 705-713. [CrossRef]

40. Carter, T.C.; Menzel, M.A.; Chapman, B.R.; Miller, K.V. Partitioning of food resources by syntopic eastern red (Lasiurus borealis), Seminole (L. seminolus) and evening (Nycticeius humeralis) bats. Am. Midl. Nat. 2004, 151, 186-191. [CrossRef]

41. Clare, E.L.; Fraser, E.E.; Braid, H.E.; Fenton, M.B.; Hebert, P.D.N. Species on the menu of a generalist predator, the eastern red bat (Lasiurus borealis): Using a molecular approach to detect arthropod prey. Mol. Ecol. 2009, 18, 2532-2542. [CrossRef]

42. Griffith, E.G.; Bryce, A.S.; Omernik, M.J.; Comstock, A.J.; Rogers, C.A.; Harrison, B.; Hatch, L.S.; Bezanson, D. Ecoregions of Texas (color poster with map, descriptive text, and photographs); U.S. Geological Survey: Reston, VA, USA, 2004.

43. United States Department of Agriculture [USDA]. 2007 Census of Agriculture National Agricultural Statistics Service; Summary and State Data: Washington, DC, USA, 2009; Volume 1, Part 51.

44. United States Department of Agriculture [USDA]. 2012 Census of Agriculture National Agricultural Statistics Service; Summary and State Data: Washington, DC, USA, 2014; Volume 1, Part 51.

45. Kunz, T.H. Feeding ecology of a temperate insectivorous bat (Myotis velifer). Ecology 1974, 55, 693-711. [CrossRef]

46. Ross, A. Ecological aspects of the food habits of insectivorous bats. Proc. West. Found. Vertebr. Zool. 1967, 1, 205-264.

47. Ross, A. Notes on food habits of bats. J. Mammal. 1961, 42, 66-71. [CrossRef] 
48. King, R.A.; Read, D.S.; Traugott, M.; Symondson, W.O.C. Molecular analysis of predation: A review of best practice for DNA-based approaches. Mol. Ecol. 2008, 17, 947-963. [CrossRef] [PubMed]

49. Deagle, B.E.; Tollit, D.J. Quantitative analysis of prey DNA in pinniped faeces: Potential to estimate diet composition? Conserv. Genet 2006, 8, 743-747. [CrossRef]

50. Deagle, B.E.; Thomas, A.C.; Shaffer, A.K.; Trites, A.W.; Jarman, S.N. Quantifying sequence proportions in a DNA-based diet study using Ion Torrent amplicon sequencing: Which counts count? Mol. Ecol. Resour. 2013, 13, 620-633. [CrossRef]

51. Folmer, O.; Black, M.; Hoeh, W.; Lutz, R.; Vrjenhoeck, R. DNA primers for amplification of mitochondrial cytochrome c oxidase subunit I from diverse metazoan invertebrates. Mol. Mar. Biol. Biotechnol. 1994, 3, 294-299.

52. R Core Team. R: A Language and Environment for Statistical Computing; R Foundation for Statistical Computing: Vienna, Austria, 2013.

53. Bates, D.; Maechler, M.; Bolker, B. Ime4: Linear mixed-effects models using S4 classes, R package version 0.999999-0. 2012. Available online: http://CRAN.R-project.org/package=lme4 (accessed on 9 November 2019).

54. Pinheiro, J.; Bates, D.; DebRoy, S.; Sarkar, D.; R Development Core Team. nlme: Linear and Nonlinear Mixed Effects Models, R package version 3.1-105: 2012. Available online: https://CRAN.R-project.org/package=nlme (accessed on 11 November 2019).

55. Babyak, M.A. What you see may not be what you get: A brief, nontechnical introduction to overfitting in regression-type models. Psychosom. Med. 2004, 66, 411-421.

56. Burnham, K.P.; Anderson, D.R. Model Selection and Multimodel Inference: An Information-Theoretic Approach; Springer Science: New York, NY, USA, 2002.

57. Hothorn, T.; Bretz, F.; Westfall, P. Simultaneous inference in general parametric models. Biom. J. 2008, 50, 346-363. [CrossRef]

58. Booth, G.; Niccolucci, M.; Schuster, E. Identifying Proxy Sets in Multiple Linear Regression: An Aid to Better Coefficient Interpretation; Research paper INT-470; United States Department of Agriculture, Forest Service: Ogden, UT, USA, 1994.

59. Zuur, A.F.; Leno, E.N.; Walker, N.J.; Savaliev, A.A.; Smith, G.M. Mixed Effects Models and Extensions in Ecology with R; Springer Science+Business Media: New York, NY, USA, 2009.

60. Boyles, J.G.; Sole, C.L.; Cryan, P.M.; McCracken, G.F. On Estimating the Economic Value of Insectivorous Bats: Prospects and Priorities for Biologists. In Bat Evolution, Ecology, and Conservation; Adams, R.A.P.S.C., Ed.; Springer: New York, NY, USA, 2013; pp. 501-515.

61. Cleveland, C.J.; Betke, M.; Federico, P.; Frank, J.D.; Hallam, T.G.; Horn, J.; Lopez, J.D.; McCracken, G.F.; Medellin, R.A.; Moreno-Valdez, A.; et al. Economic value of the pest control service provided by Brazilian free-tailed bats in south-central Texas. Front. Ecol. Environ. 2006, 4, 238-243. [CrossRef]

62. Kalka, M.B.; Smith, A.R.; Kalko, E.K.V. Bats limit arthropods and herbivory in a tropical forest. Science 2008, 320, 71. [CrossRef]

63. Williams-Guillen, K.; Perfecto, I.; Vandermeer, J. Bats limit insects in a neotropical agroforestry system. Science 2008, 320, 70. [CrossRef]

64. Perry, R.W.; Thill, R.E.; Carter, S.A. Sex-specific roost selection by adult red bats in a diverse forested landscape. For. Ecol. Manag. 2007, 253, 48-55. [CrossRef]

65. Limpert, D.L.; Birch, D.L.; Scott, M.S.; Andre, M.; Gillam, E. Tree selection and landscape analysis of eastern red bat day roosts. J. Wildl. Manag. 2007, 71, 478-486. [CrossRef]

66. Barbour, R.W.; Davis, W.H. Bats of America; University Press of Kentucky: Lexington, KY, USA, 1969.

67. Menzel, J.M.; Menzel, M.A.; Kilgo, J.C.; Ford, W.M.; Edwards, J.W.; McCracken, G.F. Effect of habitat and foraging height on bat activity in the coastal plain of South Carolina. J. Wildl. Manag. 2005, 69, 235-245. [CrossRef]

68. Thomas, H.H.; Moosman, P.R.; Veilleux, J.P.; Holt, J. Foods of bats (family Vespertilionidae) at five locations in New Hampshire and Massachusetts. Can. Field-Nat. 2012, 126, 117-124. [CrossRef]

69. Farney, J.; Fleharty, E.D. Aspect Ratio, Loading, Wing Span, and Membrane Areas of Bats. J. Mammal. 1969, 50, 362-367. [CrossRef]

70. Fitch, J.H.; Shump, K.A., Jr.; Shump, A.U. Myotis velifer. Mamm. Species 1981, 149, 1-5. [CrossRef]

71. Lee, Y.F.; McCracken, G.F. Dietary variation of Brazilian free-tailed bats links to migratory populations of pest insects. J. Mammal. 2005, 86, 67-76. [CrossRef] 
72. Clem, P.D. Foraging patterns and the use of temporary roosts in female evening bats, Nycticeius humeralis, in an Indiana maternity colony. Proc. Indiana Acad. Sci. 1993, 102, 201-206.

73. Wilkinson, G. Communal nursing in the evening bats. Nycticeius humeralis. Behav. Ecol. Sociobiol. 1992, 31, 225-235.

74. Feldhammer, G.A.; Whitaker, J.O., Jr.; Krejca, J.K.; Taylor, S.J. Food of the evening bat (Nycticeius humeralis) and red bat (Lasiurus borealis) from southern Illinois. Trans. Ill. Acad. Sci. 1995, 88, 139-143.

75. Millar, J.G.; Knudson, A.E.; McElfresh, J.S.; Gries, R.; Gries, G.; Davis, J.H. Sex attractant pheromone of the pecan nut casebearer (Lepidoptera: Pyralidae). Bioorganic Med. Chem. 1996, 4, 331-339. [CrossRef]

76. Calcote, V.R.; Smith, J.S.; Hyder, D.E. Pecan nut casebearer (Lepidoptera: Pyralidae): Seasonal activity and mating frequency in central Texas. Environ. Entomol. 1984, 13, 196-201. [CrossRef]

77. Elkinton, J.S.; Cardé, R.T. Effect of wild and laboratory-reared female Gypsy moths, Lymantria dispar L. (Lepidoptera: Lymantriidae), on the capture of males in pheromone-baited traps. Environ. Entomol. 1984, 13, 1377-1385. [CrossRef]

78. Knight, A.L.; Croft, B.A. Temporal patterns of competition between a pheromone trap and caged female moths for males of Argyrotaenia citrana (Lepidoptera: Tortricidae) in a semienclosed courtyard. Environ. Entomol. 1987, 16, 1185-1192. [CrossRef]

79. Kondo, A.; Tanaka, F. Effect of wild virgin females on pheromone trap efficiency in two annual generations of the rice stem borer moth, Chilo suppressalis (Walker) (Lepidoptera: Pyralidae). Appl. Entomol. Zool. 1994, 29, 279-281. [CrossRef]

80. Lacki, M.J.; Hayes, J.P.; Kurta, A. (Eds.) Bats in Forests: Conservation and Management; The Johns Hopkins University Press: Baltimore, MD, USA, 2007.

81. Braun de Torrez, E.C.; Samoray, S.T.; Silas, K.A.; Wallrichs, M.A.; Gumbert, M.W.; Ober, H.K.; McCleery, R.A. Acoustic lure allows for capture of a high-flying, endangered bat. Wildl. Soc. Bull. 2017, 41, 322-328. [CrossRef]

82. O'Shea, T.J.; Cryan, P.M.; Hayman, D.T.S.; Plowright, R.K.; Streicker, D.G. Multiple mortality events in bats: A global review. Mammal Rev. 2016, 46, 175-190. [CrossRef]

83. Clark, D.R., Jr.; Shore, R.F. Chiroptera. In Ecotoxicology of Wild Mammals; Shore, R., Rattner, B., Eds.; John Wiley \& Sons: Chichester, West Sussex, UK, 2001; pp. 159-214. 